\title{
Sperm and ova as property
}

\author{
Robert P S Jansen Royal Prince Alfred Hospital, Sydney, Australia
}

\section{Author's abstract}

To whom do sperm and ova belong? Few tissues are produced by the human body with more waste than the germ cells. Yet dominion over the germ cells, and over the early embryo that results from their union in vitro, is behind much of the emotion that modern reproductive intervention can engender. The germ cells differ from other human tissues that can be donated or transplanted because they carry readily utilisable genetic information. Eventual expression of the germ cells' genetic potential is the legitimate concern and responsibility of their donors, although in the right circumstances the responsibility can by agreement be entrusted to institutions administering gamete or embryo donor programmes; these institutions, in turn, may need to assume responsibility for decisions if, in the case of embryo storage, the wishes of the two donors conflict. The fact of sperm and ovum ownership (and the genetic potential that goes with it) before individuals part with these tissues is beyond dispute. Some contentious issues may be clarified if this area of human dominion, namely control over genetic expression among offspring, is acknowledged to be the legitimate persisting concern of those who have produced sperm and ova after storage commences.

Who cares about what happens to our sperm or about what happens to our ova? Does anyone care about the fate of the sperm produced from a man's seminiferous tubules or the eggs produced from a woman's ovaries? Should one care? Is one allowed to care? These questions and their answers are important quantitatively and qualitatively.

First, quantitatively. We can look at the numbers of eggs (the term 'eggs' includes oocytes and ova) for which a woman might assume responsibility. All the oocytes that a woman will ever produce are formed during fetal life - by four months from the time she herself was conceived (1). So, five months before birth

\section{Key words}

Medical ethics; in vitro fertilisation; law of contract; cloning; tissue transplantation; embryo transfer; cell culture; tissue culture. the human female has all the eggs she will ever have about 7 million. Oocyte loss begins before she is born. By the time of birth 1 or 2 million eggs remain. Even $\overrightarrow{-}$ before birth the process of atresia, in which oocytes start their development only to degenerate and be lost has almost decimated the oocyte population. By puberty, at which time oocytes become candidates for ovulation and, perhaps, fertilisation, only abouts 300,000 are left. Then, if one of these 300,000 eggsD ovulates each month for the twenty-five years, say, that constitute the reproductive years, it is clear that only about 300 eggs have any chance at all of ending up aș babies. Indeed, because of opportunities lost during pregnancy there is not the time for more than about $\mathrm{s}_{0}^{\circ}$ or 20 of the eggs (69 if multiple ovulations are included (2) to become babies. The other 299,000 or more क्षेe destined for oblivion.

The attrition of gametes is even more spectaculan among men. If a man with an average sperm counp ejaculates, say, 6000 times in his lifetime, he will hav® let loose upon the world, or its drainpipes, no fewe $\overrightarrow{\bar{\sigma}}$ than one thousand thousand million potentia $B$ fertilisers-of-an-egg. Of these spermatozoa, perhaps $F$ or 3 or 200 , at most an infinitesimal fraction, are likely? to find successful expression by fertilising an egg that will ultimately become another individual.

Does anyone care that all these sperm and ova are wasted? Not likely. Not only would it be futile for even. the most dedicated of us to have more than a marginap impact on the number of sperm and ova lost, but it would, in a well populated world, be arrogant anc irresponsible. This notion of responsibility, which stop\& most people taking part in all-out promiscuous: procreation, is one side of the qualitative considerations we bring to bear on the destiny we will allow even one sperm or one ovum.

Why the dichotomy? Why could we not care lessw about the millions of sperm washed out of the linen of about the thousands of eggs that might, with a stroke of the scalpel, accompany a surgically removed ovary int $\Phi$ the formalin bottle, when the fate of one ovum, of one frozen straw of spermatozoa, let alone the fate of an early embryo (3), fills so many people with emotion $\frac{\text { Oे }}{\mathrm{D}}$ What is it about them that makes sperm and ov? different from arms and legs or a pint of blood?

Notwithstanding some modern America促 
challenges (4), the courts of common-law countries such as Australia and the United Kingdom have held that once organs or tissues are separated from a person that person (if alive, or that person's estate if dead) has little or no right of ownership or legally-enforceable control over the separated parts. Human body parts in law appear simply to be incapable of being owned (5). Nevertheless in medical practice an agreement is often implied whereby the use to which separated tissues might be put is limited. For example, kidney transplants from living donors, who are put at considerable risk through the fact of the donation, are carried out with the clear understanding that the recipient will be the individual identified by the donor. Similarly, if a person's limb is severed in an accident and accompanies him to the hospital, the surgeon attempting to sew it back on is presumably under some sort of obligation not to graft it to someone else. But if the kidney transplant fails, or if the limb is unsuitable for use, the law does not recognise the person who provided it as having any particular provenance over it: the tissue, for example, cannot automatically be taken home or sold to a museum.

Perhaps, in the absence of specific laws to the contrary, this lack of firm dominion over body parts or tissues could also apply to sperm kept frozen in a sperm bank for donation (a common practice) and to spare ova that may be fertilised and donated (so far an uncommon practice) (6). Yet it is unthinkable for a woman, having been put at some risk and discomfort, to lose claim to an ovum recovered for the purpose of in vitro fertilisation, and for the embryologist at whim to use the ovum for another purpose. It is also unattractive to imagine that sperm, stored for a man embarking on a course of cytotoxic drugs that might jeopardise his fertility, could be used for any purpose other than the express one for which the semen is being stored - namely to impregnate that man's wife. Ignoring the directions of the donors of sperm or ova would not be contemplated in responsible institutions and an agreement, implicit or explicit, exists between the donor and the storing institution or agency.

So far in my argument I have not yet developed any real difference (other than the obvious difference in purpose) between the agreements that govern deposition of gametes for storage and, say, live-donor kidney transplantation. The fact that gametes can be stored for many years is not very important. It could be argued that all that cryostorage does is to allow the special purpose's realisation to be postponed; that, given appropriate techniques, kidneys could be stored for just as long. A more basic difference between the two types of donation is that sperm donations do not put the donor at risk; when the technology for harvesting immature oocytes develops, ovum donations, too, will presumably be incidental to a surgical operation performed for another reason and so carry no added physical risk; embryo donations are usually made after the event of fertilisation, when there is also no added risk or physical discomfort for the donor. Another difference is that the providers of the isolated tissue, whether sperm, ovum or embryo, do not always have the same immediate objective of relieving suffering for a relative (as would the live donor of a kidney) or for themselves (in the case of a severed limb); in this sense gamete donations are often more like donations of blood or even like agreements to donate kidneys, a liver or a heart in the event of death - donations made without a specific recipient in mind. But blood for transfusions or promises of posthumous kidney donations are unlikely to carry for the donors much more mental impact than a moderate sense of altruism, whereas dispossession of gametes or embryos is capable of causing a great deal more concern. Indeed, the contrast is striking.

With a gamete donation or an embryo donation there is a donation of genetic information. This is a special attribute that the reproductive tissues, the germ cells, do not share with other tissues. Even though these other tissues contain millions of living cells, each carrying all the genetic information needed to code for the synthesis of a person, the specific difference is that the genetic information carried by sperm and ova is usable. It is this single fact that makes the gametes so special. When our sperm or ova go down the drain we generally could not care less (unless for some reason there are no more sperm or ova to take their place). The reason we do not care is that once down the drain the information they contain, in practical terms, is not usable: it will never find genetic expression: it will never mix with another germ cell's information to produce a new individual: we can forget about it.

Interestingly, the law is coming to grips with the sanctity of information-content in several spheres. For example, copyright laws exist to cover not just verbal prose and illustrations but are also being considered to cover the steps and strategies involved in computer programs (7). The United States Supreme Court has ruled that the cloned genetic material of bacteria used to manufacture the human proteins insulin and growth hormone through recombinant DNA technology is protected: this genetic material, this biological stuff that contains information, can be patented $(8,9)$. There is therefore some precedent for distinguishing the usable genetic information contained in sperm and ova from the much less readily usable genetic information contained in the cells of a donated kidney or an amputated leg.

The uniqueness of sperm and ova may be brought out further with another analogy. Manufacturers of silicon chips, used in computers, have apparently had problems keeping the design of their integrated circuits protected from those who want to copy them for easy commercial gain - from those who simply buy one of these complicated but cheap bits of silicon and etch them away slowly, layer by layer, to decipher the information they contain, copy the chip's circuitry, and so cheat the original chip maker from the fruits of building up the information from nothing. It's reported that chip makers can discourage these tactics 
by incorporating confusing elements, dummy circuits, which look like working parts but which, when copied, make the copy inoperable (7). What the chip makers are protecting is not the chip itself - a chip's extrinsic value is only a few pounds - but the usable information coded into the chip's structure.

In the same way, each ejaculate or each ovulation hardly constitutes a major drain on an individual's resources. One simply does not care if ejaculates or ova are lost - provided that they are actually lost and that their information content, their genetic potential, is not going to be realised in a way one's not happy with. It is this substantial potential that ova and sperm have, through the usable information they contain, that compels their use in donor programmes to be quite unlike that of other parts of the body. This potential should always remain the responsibility, the provenance, the dominion, perhaps the property, of the donor.

The Warnock Committee expressed the hope that a couple party to in vitro fertilisation would recognise their responsiblity to make firm decisions on use and disposal of any embryos kept in storage (10). But the Warnock report also recommends 'that legislation be enacted to ensure there is no right of ownership in a human embryo'. One presumes this suggestion is intended to stop commercial trade in embryos, in which case less indignation among owning couples might follow a more simple recommendation to make such trade illegal, together with formalising the rights of institutions or storage authorities (or their ethics committees) to make decisions in difficult situations. Making recommendations similar to those advocated in 1982 by the National Health and Medical Research Council (NH and MRC) in Australia (11), the Warnock report advises that when one of a couple dies the right to use or dispose of any embryo stored by that couple should pass to the survivor; in the event of 1) the absence of a survivor, 2) a dispute among the couple, or 3 ) the elapse of the time of normal reproductive need of the couple (generally of the order of 10 years) the storage institution (11) or authority (10) should have the power to make decisions, which in the NH and MRC's research guidelines, but not in the Warnock report, are taken to mean a decision to dispose of rather than to use the embryo. Despite this apparent difference in managing situations when no instructions exist, everyone agrees that donors' wishes on use or disposal should, as far as possible, be explicit well before the need to make such decisions arises.

The Warnock report may underestimate the stake donors or providers might have in the fate of their sperm, ova or embryos. The Warnock inquiry expressed 'grave misgivings' about Artificial Insemination with semen from a Husband (AIH) who has died but who has left semen in a sperm bank, the misgivings apparently being based on possible psychological problems for the child and the mother (10). Moreover, any child born by AIH not in utero at the date of the death of its father shall, according to Warnock's recommendations (10), be disregarded form the purposes of succession to and inheritance from the $\overrightarrow{\overline{7}}$. father (although not, presumably, from rights of? inheritance from the mother). My conclusions on $\vec{F}$ sperm and ovum provenance or dominion based on their genetic potential may put these inflexible응 recommendations in a different light.

A woman chooses not just a companion when she $\frac{\widehat{D}}{\widetilde{D}}$ marries but also a father to her children, someone to complement her genetically and help endow heros children with traits she considers desirable. This, in $\vec{\circ}$ my view, gives her substantial justification, if herhusband's semen has been stored, to continue to have $\vec{\sigma}$ access to it after his death, he not having disagreed and her medical attendants being willing to help. It would be quite unfair of society to insist that she think again (and so marry again) in her quest for children.w Moreover men often store semen when they learn they $\vec{N}$ have a life-threatening disease. On the face of it the ${ }^{\omega}$ motive may seem to be that they are to receive cancer-응 killing drugs which are likely, as a side-effect, to destroy the sperm-forming tissues in the testes. But $\mathbb{D}$ from my contact with these men I am aware they often $\frac{0}{\mathbb{D}}$ have another motive: to preserve their genetic potential in the event that they die as a result of their disease. Many dying patients take comfort in the fact that they have children, that it is not the end of the rogd genetically. On the other hand among the causestof anguish adolescents have in facing death 행응 unfulfilment of their procreative instincts. This dọess not give society an obligation to use reproductive technology to fulfill these desires, but, because theू implied motive in leaving stored semen behind aftero death is the wish for it to be used to secure offspring, an explicit or testamentary wish for passage of inheritances rights during the reproductive life of the wife should, if she wants it that way, be allowed. Similarly the deathọ through non-inheritable cause of a gamete donos should not necessarily mean withdrawal of his or hero gametes from a donor programme.

It may soon become possible for the genetic potentia?. of non-germ (somatic) cells to be realised. Oneo technique that has already been successfully carried out in frogs, at least to the stage of producing tadpoles(12), consists of transferring an adult somatio cell's nucleus to a recently fertilised or activated ovum. whose own nucleus has been removed. A mature ovumn has the chemical machinery to strip off the basie proteins that normally mask much somatic celis deoxyribonucleic acid (DNA) (it does the same to the tightly packed DNA from the sperm nucleus afte fertilisation) and the ovum may then read that DNA, as cell division gets underway, in exactly the manner iro which, a generation before, the same DNA started the life of the individual from whom the somatic cell wașo obtained. The second individual will be a precise genetic replica of the first.

Development of this cloning technology, ethically疋 and socially aborrhent though it might be, would 
confer on somatic cells the same property, usable genetic information, that today distinguishes the germ cells. It is entirely plausible that the somatic cells most suitable or closest at hand for such experiments would come from aborted fetuses or from more or less standardised human cell lines kept in tissue culture for various purposes. Ms Henrietta Lacks, in 1951 a 31year-old black woman but now long dead from cancer of the cervix, has endowed the world's tissue-culture laboratories with ' $\mathrm{HeLa}$ ' cancer cells for viral cultures (13). The distribution of HeLa cells has become so widespread and the reported research based on HeLa cells has become so voluminous that Index Medicus has immortalised her with her own category. True, her DNA has probably been changed beyond recognition both by the cancer's original neoplasia and by subsequent transformation in culture, but that is not the point. The possibility remains that the witting or unwitting donor of any tissue could quite soon be put in the position of having himself or herself genetically replicated.

Society's intention to exert ethical control over human reproductive research is evident in many Western democracies today and it is unlikely that any scientist carrying out human cloning experiments, let alone using DNA from unsuspecting donors, would do so without alarming his or her peers and scandalising the community. But the technical possibility of such cloning experiments needs to be taken into account. The NH and MRC in Australia, in its guidelines on ethics in medical research involving the fetus and human fetal tissue (14), advises that specific consent be sought from at least the genetic mother for the use of fetal tissues in any research that involves live-cell storage, propagation in tissue culture, or transplantation into a recipient human being. It should be clear that maintaining cells alive for research is no longer the same as preserving dead cells in formalin.

Whereas cloning, if at all, is for the future, ownership of the genetic information contained in sperm and ova is with us now. The fact of this ownership, at least before one parts with sperm or ova in any way that allows this information to be used, lies behind much of the concern that accompanies gamete donation and the development of human embryos in vitro. Some of the debated issues would be clarified by acknowledging that this area of human dominion, namely control over genetic expression among offspring, is still important after sperm, ova or embryos are parted with.

I thank Russell Scott LL B for our discussions.

\section{Acknowledgement}

This paper is based on an address delivered at the centenary celebrations of Royal Prince Alfred Hospital in Sydney.

Robert fansen $M B, B S, B S c(M e d), \quad F R A C P$, MRCOG, FRACOG is Visiting Gynaecologist, Royal Prince Alfred Hospital, Sydney 2050, Australia.

\section{References}

(1) Baker T G. Oogenesis and ovarian development. In: Balin H, Glasser S, eds. Reproductive biology. Amsterdam: Excerpta Medica, 1972; 398-437.

(2) Anonymous. Reproductivity; motherhood; most children; world. In: McWhirter N, ed. Guinness book of records. (29th ed) Enfield, Middlesex: Guinness Superlatives, 1983: 17.

(3) Holden C. Two fertilised eggs stir global furor. Science 1984; 225: 35.

(4) Anonymous. Patient sues for title of own cells. Nature 1984; 311: 198.

(5) Scott R. The body as property. London: Allen Lane, 1981: 6-7, 186-197.

(6) Trounson A, Leeton J, Besanko M, Wood C, Conti A. Pregnancy established in an infertile patient after transfer of a donated embryo fertilised in vitro. British medical journal; 286: 835-838.

(7) The economist 1982 May 19: 93.

(8) The economist 1982 Jan 16: 84.

(9) Beardsley T. Cohen-Boyer patent finally confirmed. Nature 1984; 311: 3 .

(10) Warnock M. (Chairman): Report of the committee of inquiry into human fertilisation and embryology. London: Her Majesty's Stationery Office, 1984: 18, 55-57.

(11) National Health and Medical Research Council. Ethics in medical research. Canberra: Australian Government Publishing Service, 1983: 26-28.

(12) McLaren A. Methods and success of nuclear transplantation in mammals. Nature 1984; 309: 671672.

(13) Jones H W Jr, McKusick V A, Harper P S, Wuu K D, George Otto Gey (1899-1970). The HeLa cell and a reappraisal of its origin. Obstetrics and gynaecology 1971; 38: 945-949.

(14) National Health and Medical Research Council. Ethics in medical research involving the human fetus and human fetal tissues. Canberra: Australian Government Publishing Service, 1983: 17-19. 